\title{
Homenaje a León Felipe en sus ochenta años
}

Aquí estamos, con corazón unánime, en numerosa familia republicana y fraternidades mexicanas, para honrarnos honrando, en acto de presencia, a un hombre, León Felipe, que cumple altura de años y anchura de obra. Simple delegado -por amigo y por hombre también de palabra- ofrezco en nombre de todos el homenaje a nuestro poeta: el espíritu que aquí preside, la representación de El juglarón, por la Compañía del Teatro Popular Independiente, dirigida por Lorenzo de Rodas, y luego Ofelia* encarnará una voz ante la cual no hay ningún sordo aquí. Pero antes... escuchadme:

León Felipe dijo una vez que llegó al templo nacional de la Poesía española cuando se a pedreaba en las calles a los últimos sacerdotes simbolistas. Llegó tarde, y cansado, y por unos extraños atajos pedregosos. No entró por la puerta tradicional ni por los boquetes que abrían en las viejas paredes una cuadrilla de jóvenes poetas revolucionarios, allá por los años 191820. El nos dice que en realidad no era más que un vagabundo sin casa, sin credo y sin escuela, que andaba perdido por los cafés y por las calles de Madrid. Y yo digo que ya era el hombre prometeico que podía decir: "Lloro, grito, aúllo, blasfemo... luego existo".

La poesía de León Felipe casi no tiene nada que ver con la palabra jerarquizada. Diríase que es una poesía que odia a las palabras, simple material de honda para él, alucinado pastor de la justicia, hombre de raíz y de llanto, de lo que se hunde en la tierra y de la lágrima que socava. Poeta con la conciencia grávida de destrucciones y de apocalipsis, voz de incendios, ha caminado sin embargo sobre el hilillo de luz de la estrella de los nacimientos y ha procurado convencerse de que hay a maneceres. Como el Viento, la gran metáfora de su poesía, no sabemos de dónde viene y él, nos diria, no va a ninguna parte: toda ida es un regreso, y todo regreso un salario de sombra que hay que pagar a la luz.

* La actriz española Ofelia Guilmain 
Como español, sin embargo, León Felipe heredó de la trágica angustia de Quevedo, de la rabia demoled ora y visionaria de Goya y de las imágenes del aquelarre social de Gutiérrez Solana. Se le ha comparado a menudo con Walt Whitman. La semejanza, creo yo, es superficial y limitada únicamente a dos coincidencias externas: individualismo como afirmación de libertad y torrencial impulso. Whitman todavía pudo considerar a la democracia como valor determinante de cohesión solidaria en el momento germinal de la nación a que pertenecía, y cantó la alegria de la vida con acentos adámicos. Fue un poeta de auroras. León Felipe, en cambio, es un pcieta mordido de sombras, un épico de los símbolos ( Dadme un símbolo -podría decir- y levantaré la conciencia!) y es como el buhonero metafísico de su propio dolor de vivir en un mundo sin inocencia. O mejor: es como el Viento convertido en un errante Edipo lleno de enigmas sin respuesta y guiado por una. Antígona roja: la. Canción rota.

Sí, una tremenda nostalgia de la inocencia desgarra el espíritu de León Felipe y forma el núcleo central de donde brota mucha de su poesía a pleno pulmón, a plena llaga, a plenos odres de sollozos. Lo hubiera dado todo León Felipe para poder ser un mesías de la esperanza solar del hombre sobre la tierra, y hasta durante algún tiempo esperó la aurora profunda "entre una blasfemia y una oración podrida".

En Ganarás la luz, León Felipe se identifica reiteradamente con dos mitos cuyo valor es antagónico y confirma la dicotomía de su espíritu: Jonás y Prometeo.

“Soy yo el Jonás español? ¿Seré yo el recién nacido? ¿El que acaba de dejar las entrañas? Por eso he dicho que tal vez me llame Jonás. Y que acaso este libro es la aventura de Jonás: la noche oscura, su estancia en la ballena, la vida del hombre en el infierno".

Opuesto a Jonás, mito del regreso a los orígenes, a la matriz primordial, se levanta el de Prometeo, el héroe que desafió a Zeus y robó el fuego para los hombres.

"Abro la puerta roja de mi pecho para dar de beber a las estrellas, y la sangre mía que se llevan es la savia por donde voy ascendiendo al elevado reino de la luz". 
De esta experiencia, para el León Felipe de Ganarás la $l u z$, hombre cuyo espíritu está de bruces sobre su corazón, donde le hereda... habrán de salir los principios de la nueva poesía del futuro, la poesía prometeica de la llamá, que será una épica social. Así, el hombre de las profundidades -Jonásel rebelde sangrante de las cimas -Prometeo-y el poeta, sacerdote de los mitos, serán juntos los codificadores del mundo. Esto es lo que nos importa. Luego el poeta, en su infinita libertad, irá viviendo caídas y ascensiones, podrá sentirse "un hombre con un grito de estopa en la garganta y una gota de asfalto en la retina". ¿Vence Jonás o vence Prometeo? Sabemos una cosa: el hombre que anhela ganar la luz es que ya la lleva en su propia alma.

La has ganado, León Felipe, y no para ti solo. En la cornamenta de tu Ciervo puede enroscarse la serpiente de la sombra, pero si no hubiera luz, no la veríamos... Y luego nos quedas tú, la proximidad viva del hombre que amamos, del amigo que llega a casa a vernos con sus ternuras y sus ausencias, y se sienta junto al fuego envuelto en su capa de viento invisible o que vemos alejarse por una arbolada avenida de la ciudad de México, con su lento andar de pastoreo cósmico y su rostro de Ecce Homo invadido de primavera...

León Felipe: en nombre de todos te digo una última palabra: nuestro, nuestro, nuestro. Como la libertad de cabeza roja, tú y tu obra seguís andando, andando, León Felipe nuestro, andando... 